CLINICAL STUDY

\title{
Secretion of inhibin B by human prepubertal testicular cells in culture
}

\author{
E Berensztein, N Saraco, A Belgorosky and M A Rivarola \\ Research Laboratory, Garrahan Pediatric Hospital, Buenos Aires, Argentina \\ (Correspondence should be addressed to M A Rivarola, Endocrinología, Hospital de Pediatría Garrahan, C. de los Pozos 1881, Buenos Aires, \\ Argentina (1245); Email: mariv@impsat1.com.ar)
}

\begin{abstract}
Objective: Inhibin B is a secretory product of Sertoli cells of the human testis. It has been reported that serum levels of inhibin B in infant boys, peaking at 3 months of age, exceed levels in adult men. The aim of this study was to evaluate inhibin B secretion in primary prepubertal mixed testicular cell cultures, prepared from testes collected at necropsy.

Design and Methods: Cell cultures were divided into three age groups on the basis of differences in testicular histology: group $1(n=7), 1$ - to 10-day-old newborns, group $2(n=7), 1$ - to 9-month-old infants, and group $3(n=8), 12$ - to 84-month-old children. Cells were maintained in culture for 6 days, harvested and counted. In some samples, during the last 4 days, cells were stimulated with $10 \mathrm{ng} / \mathrm{ml}$ highly purified human (h) LH $(n=9), 2 \mathrm{ng} / \mathrm{ml}$ recombinant human ( $\mathrm{rh}) \mathrm{FSH}(n=9)$ or $50 \mathrm{ng} / \mathrm{ml} \mathrm{rhGH}(n=4)$. On day 6 , the secretion of inhibin B and testosterone into the medium was estimated in triplicate. Inhibin B was determined by ELISA and testosterone by RIA.

Results: Median (range) inhibin B secretion was 465 (225-1007), 275 (107-298), and 58 (15-184) $\mathrm{pg} /$ million cells. $24 \mathrm{~h}$ in groups 1, 2 and 3 respectively. A logarithmic transformation of these values was performed to normalize data. Mean \pm S.D. of transformed inhibin B secretion in group 1 was significantly higher than in group 2 or $3(P<0.005)$ and the values for groups 1 and 2 were significantly higher than that for group $3(P<0.005)$. No significant correlation between testosterone and inhibin $B$ secretion into the medium was found when the 22 culture samples were analyzed as a whole. Inhibin B secretion was significantly increased after stimulation with highly purified hLH, rhFSH and rhGH $(P<0.05)$ and a significant positive correlation between inhibin $\mathrm{B}$ and testosterone was found under both hLH and rhFSH stimulation.

Conclusions: It is concluded that cells collected from newborns have the highest capacity to secrete inhibin B in vitro, and that this capacity decreases with age during the first years of life. Since no data are available on serum inhibin levels in newborns, it is possible that concentrations at 3 months of age do not represent a post-natal peak but a declining level of high newborn values. As expected, FSH stimulated inhibin B secretion in culture. LH stimulation was probably mediated by paracrine factors secreted by interstitial cells. Finally, our results add new evidence of the involvement of GH in testicular maturation.
\end{abstract}

European Journal of Endocrinology 142 481-485

\section{Introduction}

It is well known that in the human male there is an increase of serum testosterone levels during the first trimester of life (1). Serum luteinizing hormone (LH) and follicle-stimulating hormone (FSH) levels also increase and the LH/FSH ratio favors $\mathrm{LH}$ in the two sexes (2), as it does in normal puberty. After the first trimester, only serum FSH remains high for a relatively long period of time, particularly in prepubertal girls. The early activation of the human testis does not seem to be confined to Leydig cells, since recently Andersson et al.
(3) have reported that in infant boys there is a peak of serum inhibin B, a possible marker of Sertoli cells, which reaches the same range level as that of adult men.

There are two major species of human inhibin, A and B. Both of them are dimeric glycoproteins (4). The main function described for inhibins is to inhibit the production and/or secretion of gonadotropins, preferentially FSH (5). Until recently, information on the physiology of human inhibins had been obtained with immunoassays which used antibodies which were not specific for each of the inhibins. The development of assays specific for the dimeric inhibins $A(6)$ and $B(7)$ has shown that 
inhibin $\mathrm{B}$, which is inducible by exogenous FSH, is the only inhibin detectable in adult men (8). In the male Rhesus monkey, Majumdar et al. (9) showed a clear stimulatory effect of FSH on inhibin levels, in contrast to the absence of effects of human chorionic gonadotropin (hCG). Inhibin B seems to be the relevant physiological inhibin involved in FSH negative feedback in the male.

Leydig cell differentiated functions are regulated by several growth factors through endocrine, paracrine and autocrine mechanisms. It has been reported (10) that neither inhibin A nor activin A have a direct steroidogenic effect but both induce an enhancement of acute hCG-induced testosterone secretion after $48 \mathrm{~h}$ of treatment. This enhancement of Leydig cell responsiveness to $\mathrm{LH} / \mathrm{hCG}$ appeared to result from a specific pattern of regulation of Leydig cell-specific gene expression. In addition, Hsueh et al. (11) reported that inhibin enhanced LH-mediated Leydig and theca cell androgen production, providing evidence of a paracrine action of this gonadal protein. Thus, testis inhibin not only suppresses pituitary FSH release but also might enhance LH-regulated Leydig cell production of androgens, which exert a negative feedback effect on LH secretion at the hypothalamo-pituitary axis.

We have previously used cultures of human prepubertal mixed testicular cells prepared from testes collected at necropsy (12) to study the age-related capacity of these cells to secrete testosterone and to respond to $\mathrm{LH}, \mathrm{FSH}$ and growth hormone $(\mathrm{GH})$ stimulation (13). The aim of the present study was to evaluate the age-related basal secretion of inhibin B by these prepubertal cells in culture, as well as their response to $\mathrm{FSH}, \mathrm{LH}$ and $\mathrm{GH}$ stimulation in vitro.

\section{Materials and methods}

Highly purified human (h) LH (NIDDK-hLH-I-SIAFP-1) was a gift from Dr A F Parlow, UCLA Medical Center, Torrance, CA, USA. FSH activity of this hLH was $0.000005 \mathrm{ng} / \mathrm{ng}$ in terms of the 2nd IRP-HMG. Recombinant human (rh) FSH (Gonal F) was a gift from Serono Laboratories (Aubonne, Switzerland). rhGH (Genotropin) was a gift from Pharmacia \& Upjohn, Buenos Aires, Argentina.

Primary cultures of prepubertal testicular cells obtained from necropsies were carried out as described previously (12). The study was approved by the Research Committee of the Garrahan Pediatric Hospital.

Cultures were divided into three age groups on the basis of differences in testicular histology. Group 1 included seven samples collected from 1- to 10-day-old newborns. Immature seminiferous cords and interstitial cells with a large eosinophilic cytoplasm and a nucleus with nucleoli with the characteristics of fetal-type Leydig cells were observed. Group 2 included seven samples collected from 1- to 9-month-old infants. Immature seminiferous cords and occasional Leydig cells were present in these testes. Group 3 was composed of eight samples collected from 12- to 84-month-old children. Immature seminiferous cords and mesenchymatous cells, but no Leydig cells, were observed in the interstitium of these testes (data not shown).

Testes were microdissected and digested twice with collagenase. Dispersed cells were seeded in DMEHamF12 with 10\% bovine fetal serum and cultured during two days. On day 2 of culture, the medium was removed and cells were washed with serum-free medium. Fresh medium without serum was added (basal condition). After a change of medium, carried out on day 4 of culture, conditioned media on day 6 of culture were collected and stored at $-20^{\circ} \mathrm{C}$ for inhibin $\mathrm{B}$ and testosterone secretion measurements in triplicate. Cells were harvested after incubation with trypsin-EDTA ( 0.5 and $0.2 \%$ respectively) for $3 \mathrm{~min}$ at $37^{\circ} \mathrm{C}$, and live cells (detected by Trypan blue exclusion) were counted with a Neubauer's chamber. In addition, in some cultures of the three groups, $10 \mathrm{ng} / \mathrm{ml}$ highly purified hLH ( $n=9,2$ of group 1, 6 of group 2 and 1 of group 3), $2 \mathrm{ng} / \mathrm{ml} \mathrm{rhFSH}(n=9,3$ of group 1,5 of group 2 and 1 of group 3$)$ or $50 \mathrm{ng} / \mathrm{ml} \mathrm{rhGH}(n=4$, 1 of group 1,3 of group 2) was added on day 2 of culture, in triplicate. Hormone stimulation was continued after a medium change on day 4 . Inhibin $\mathrm{B}$ and testosterone were determined on day 6. During culture, cells were observed using an ICM 405 Zeiss contrast phase microscope.

Testosterone was determined by radioimmunoassay as described previously (12). Inhibin B was determined using a specific enzyme-linked immuno-sorbent assay (ELISA) (Serotec Limited, Oxford, UK) and an ELISA Amplification System (Gibco, BRL Life Technologies, Gaithersburg, MD, USA). To enhance the specificity and sensitivity of the assay, samples and standards were pre-treated with detergent (SDS), heated to $100^{\circ} \mathrm{C}$, and exposed to hydrogen peroxide before the ELISA. The sensitivity of the method was $15 \mathrm{pg} / \mathrm{ml}$. Interassay coefficient of variation was less than $7 \%$.

In order to identify the different types of cells present in the primary culture of testis, the activity of $3 \beta$ hydroxysteroid dehydrogenase, as well as cytokeratin and desmin immunoreactivities were used as markers of steroidogenically active cells, Sertoli cells and myoid peritubular cells respectively.

For this purpose, on day 6 of culture, the activity of $3 \beta$-hydroxysteroid dehydrogenase was studied in the monolayer, according to the method of Steinberger (14). Briefly, cells were incubated for $90 \mathrm{~min}$ at $37^{\circ} \mathrm{C}$ in PBS containing nitro blue tetrazolium $(0.25 \mathrm{nmol} / \mathrm{l})$, NAD $(1.5 \mathrm{nmol} / \mathrm{l})$ and $3 \beta$-hydroxy- $5 \beta$-androstan- 17 one $(0.4 \mathrm{nmol} / \mathrm{l})$. A control well without steroid was stained in parallel.

Cytokeratins and desmin were detected by immunocytochemistry. All antibodies were from DAKO, Copenhagen, Denmark. To detect cytokeratins the primary antibody was a rabbit polyclonal antikeratin. This antibody was incubated for $45 \mathrm{~min}$ at $1 / 200$ 
dilution. After two washings, the second antibody, a biotinylated pig anti-rabbit antibody (1/300), was incubated for $30 \mathrm{~min}$, followed by the peroxidasebiotin-avidin conjugate $(30 \mathrm{~min}) ; 3,3^{\prime}$-diaminobenzidine was used as substrate. To identify desmin, the primary antibody was a mouse monoclonal antidesmin. It was incubated for $60 \mathrm{~min}$ at $1 / 50$ dilution; the second antibody, a biotinylated rabbit antimouse antibody, was incubated for $60 \mathrm{~min}$, followed by streptoavidin conjugated with peroxidase $(30 \mathrm{~min})$. Then, the substrate, 3,3'-diaminbenzidinetetrahydrochloride (D 5637, Sigma Chemical Co., St Louis, MO, USA) was added. Nuclei were stained with hematoxylin.

\section{Microscopic examination of cultures}

During the first day of culture, polygonal cell aggregates and dispersed isolated cells were present. Gradually, extensions of fibroblast-like cells emerged from the aggregates during the following days, forming a monolayer which surrounded the clusters (Fig. 1, panel A). After staining, it was observed that the aggregates were composed of keratin-positive, $3 \beta$ hydroxysteroid dehydrogenase-negative cells. The cell shape and staining characteristics suggested that most Sertoli cells were concentrated in the aggregates (Fig. 1,

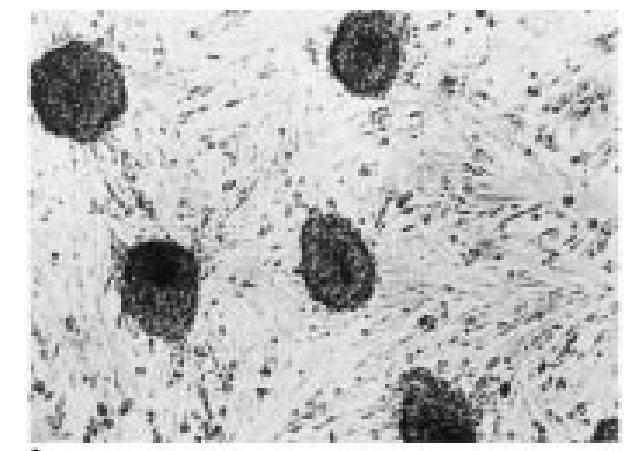

A

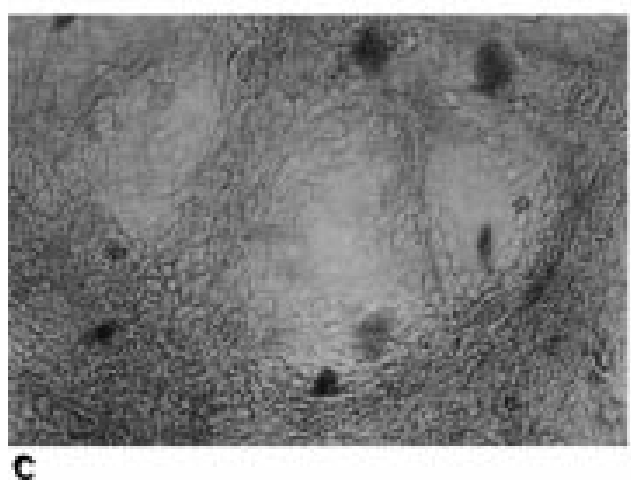

panel B). By contrast, $3 \beta$-hydroxysteroid dehydrogenasepositive elongated cells were observed in the monolayer surrounding the aggregates, indicating the localization of steroid secreting cells outside the aggregates (Fig. 1, panel C). Desmin-positive cells were also observed in the monolayer (Fig. 1, panel D), suggesting the presence of peritubular myoid cells.

\section{Statistical analyses}

Values of inhibin B were expressed as pg/million cells. $24 \mathrm{~h}$. A logarithmic transformation of those values was performed in order to normalize the data. The $t$-test was used to compare basal inhibin B secretion in the different age groups and the paired t-test was utilized to assess the effect of hLH, hFSH and hGH stimulation on inhibin B secretion. Linear regression analysis was used to evaluate the relationship between testosterone and inhibin B secretion into the medium.

\section{Results}

\section{Secretion of inhibin B on day 6 of culture}

Basal inhibin B secretion was studied on day 6 of culture in 22 primary cultures of human testicular cells. The

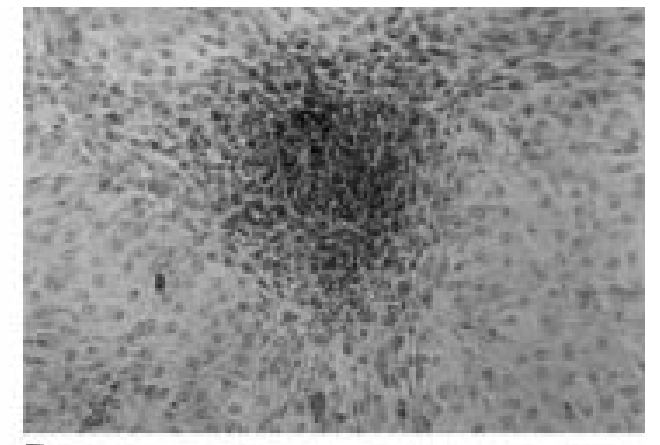

B

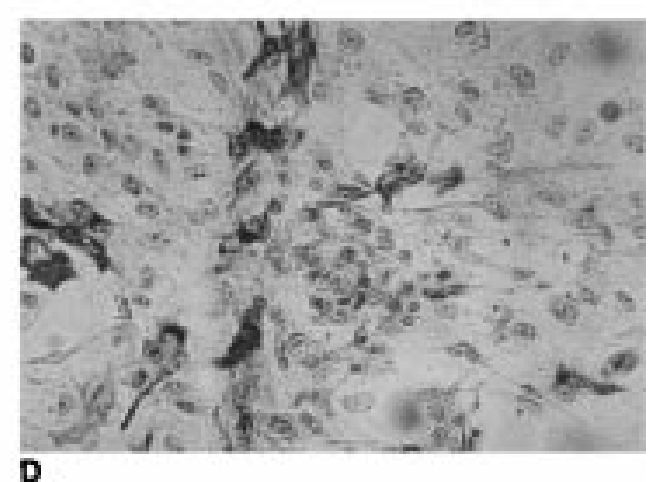

D

Figure 1 (A) Primary culture of human prepubertal testicular cells on day 6 of culture. Polygonal cell aggregates are surrounded by a monolayer of fibroblast-like cells (magnification $\times 28$ ). (B) Aggregate of keratin-positive (marker of Sertoli cells) polygonal cells surrounded by a monolayer of keratin-negative cells (magnification $\times 50$ ). (C) $3 \beta$-Hydroxysteroid dehydrogenase-positive monolayer of cells surrounding aggregates of $3 \beta$-hydroxysteroid dehydrogenase-negative cells (magnification $\times 50$ ). (D) Monolayer with sparse desmin-positive cells surrounding an aggregate without desmin-positive cells (magnification $\times 50$ ). 


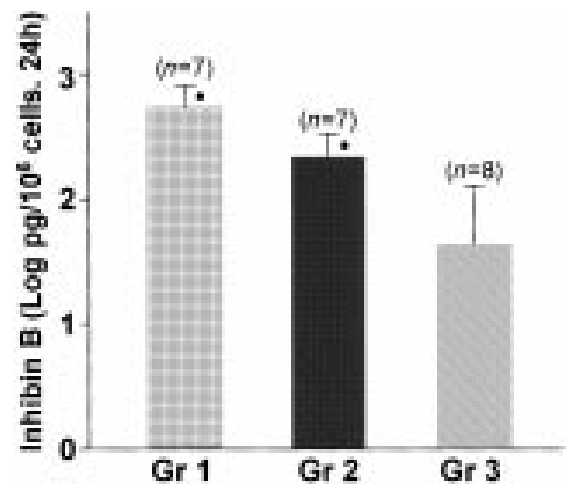

Figure 2 Secretion of inhibin B by human prepubertal testicular cells in culture in the three groups (Gr) of subjects. Values are expressed as the logarithm of $\mathrm{pg} / 10^{6}$ cells. $24 \mathrm{~h}$ (means \pm S.D.).

median values and ranges of inhibin $\mathrm{B}$ secretion in groups 1, 2 and 3 were 465 (225-1007), 275 (107$298)$ and 58 (15-184) pg/million cells. $24 \mathrm{~h}$ respectively. Figure 2 shows the secretion of inhibin B (means \pm s.D) into the conditioned medium, expressed as the logarithm of $\mathrm{pg} / \mathrm{million}$ cells. $24 \mathrm{~h}$, in the three age groups. Basal inhibin B in group $1(2.71 \pm 0.20)$ was significantly higher than in group $2(2.33 \pm 0.16)$, or group $3(1.63 \pm 0.45)(P<0.005)$ and basal inhibin $B$ in the two first groups was significantly higher than in group $3(P<0.005)$.

There was no statistically significant correlation between basal testosterone secretion and basal inhibin B secretion on day 6 of culture when the 22 cultures were analyzed as a whole.

\section{Stimulation of the secretion of inhibin $B$ with highly purified hLH, rhFSH and rhGH}

Figure 3 shows the response of inhibin B secretion after 4 days of chronic highly purified hLH, rhFSH or rhGH stimulation. There was a significant increase of inhibin $B$ secretion on day 6 in the presence of any of the three hormones $(P<0.05)$.

A significant positive correlation between testosterone $(\mathrm{x})$ and inhibin B secretion (y) was found after highly purified hLH $(\mathrm{y}=40.5+9.29 \mathrm{x}, \quad r=0.83$, $P=0.005)$ and $\operatorname{rhFSH}(\mathrm{y}=173+4 \mathrm{x}, \quad r=0.87$, $P=0.005)$ stimulation.

\section{Discussion}

Previously, we had found that basal testosterone secretion and the response to $\mathrm{LH} / \mathrm{hCG}$ stimulation of human prepubertal testicular cells in culture varied according to the age of the subjects (13). Indeed, during the first semester of life testosterone secretion was higher than in 1- to 3-year-old subjects, probably reflecting the steroidogenic potential of the testis in vivo.

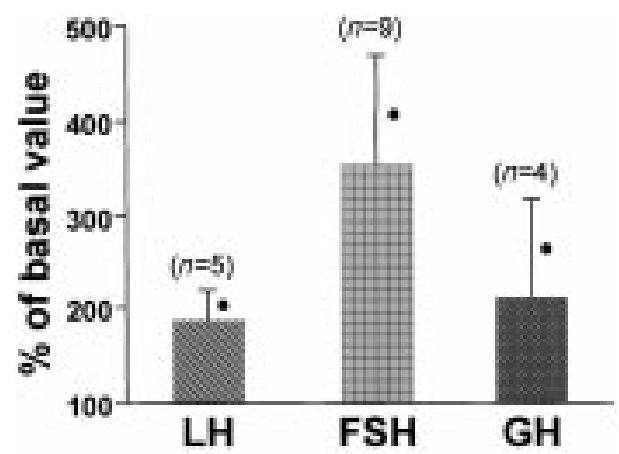

Figure 3 Secretion of inhibin B by human prepubertal testicular cells in culture: response to 4 days stimulation with $\mathrm{hLH}, \mathrm{hFSH}$ and hGH. Values are expressed as per cent of basal (means \pm S.D.).

Furthermore, testosterone secretion in culture was also stimulated by rhFSH and by rhGH.

In the present work, we have shown that inhibin B is produced by human prepubertal testicular cells in culture. The highest secretion was found in cell cultures prepared from testes of newborn subjects. In cells from testes of older infants, values were lower but still high. The lowest secretion was observed in the 1- to 7-yearold age group. These age-related changes can be compared with the variations in serum inhibin $B$ concentrations reported in prepubertal boys. In the report of Andersson et al. (3), serum inhibin B concentration in human cord blood was lower than in blood of 3-month-old infants. Cord-blood, however, is strongly influenced by placental secretion. The authors did not determine serum inhibin B levels during the first 10 days of life.

Our results suggest that the potential to secrete inhibin is at its highest level immediately after birth, during the first 10 days of life, and that it gradually declines thereafter during prepuberty, following a pattern similar to serum FSH levels (2). On the other hand, Andersson et al. (3) observed that serum inhibin $\mathrm{B}, \mathrm{FSH}, \mathrm{LH}$ and testosterone do not follow the same pattern of changes during the first year of life and concluded that inhibin B production, once activated by gonadotropins, can continue autonomously or under the stimulation of unknown factors.

As expected, we found that stimulation with $\mathrm{FSH}$ during four days in culture increased inhibin B secretion. This effect could be the result of higher secretion per Sertoli cell or of Sertoli cell proliferation, and it suggests that inhibin B could be used as a marker of Sertoli cell function or number at this prepubertal age. In addition to pituitary $\mathrm{FSH}$, paracrine factors within the testis might modulate Sertoli cell function, among them Leydig cell products (15). The lack of correlation between inhibin $\mathrm{B}$ and testosterone that we have detected would suggest that these secretions are independent. However, there was a significant increase 
of inhibin B secretion under hLH stimulation of prepubertal testicular cells in culture and there was a positive correlation between testosterone and inhibin B secretions under both hLH and rhFSH stimulation. Since LH receptors are located in Leydig cells (or Leydig cell precursors), it is possible that a secretory product of these cells stimulated Sertoli cell inhibin B secretion.

After birth, serum levels of GH and prolactin (PRL) are high, in particular during the first weeks of life (16, 17). Furthermore, receptors for GH and PRL have been described in the testes (18). The fact that the secretion of inhibin B in culture was also at its highest level when cells were collected at a very early age, and that cells increased inhibin B secretion under hGH stimulation, support the hypothesis that GH or PRL might regulate Sertoli cell function during the first months of age.

The physiological significance of the early activation of the testis is poorly understood. At this age, Sertoli cells might undergo active proliferation necessary to stimulate maturation of spermatogonia or to sustain spermatogenesis during sexual maturation at a later age. Sertoli cells might also participate in paracrine modulation of postnatal Leydig cell activation, as suggested by our previous finding of FSH stimulation of testosterone secretion in prepubertal testicular cells in culture (13).

It is remarkable that, in addition to our previous finding that testosterone secretion was stimulated by FSH, in the present study inhibin B secretion was stimulated by LH. This is in line with the observation of Andersson et al. (19) that a positive correlation between increased LH and inhibin B levels was found at the onset of puberty when no such correlation could yet be observed between inhibin B and FSH levels. Our results confirm that paracrine interactions among testicular cells modulate their activity. They might be important in the regulation of post-natal testicular function.

\section{Acknowledgements}

This work was supported by research grants from CONICET and FONCYT (Argentina) and the World Health Organization. hLH was kindly provided by Dr A F Parlow, NIDDK, USA. Gonal F and Genotropin were gifts from Serono Laboratories, Aubonne, Switzerland, and Pharmacia \& Upjohn, Buenos Aires, Argentina respectively.

\section{References}

1 Forest MG, Cathiard AM \& Bertrand JA. Evidence of testicular activity in early infancy. Journal of Clinical Endocrinology and Metabolism 197337 148-151.

2 Belgorosky A, Chain S, Chaler E, Maceiras M \& Rivarola MA. Serum concentrations of follicle stimulation hormone and luteinizing hormone in normal girls and boys during prepuberty and at early puberty. Journal of Endocrinological Investigation 1996 $1988-91$.
3 Andersson A-M, Toppari J, Haavisto A-M, Petersen JH, Simell T, Simell $\mathrm{O}$ et al. Longitudinal reproductive hormone profiles in infants: peak of inhibin B levels in infant boys exceeds levels in adult men. Journal of Clinical Endocrinology and Metabolism 1998 83 675-681.

4 Massagué J. Receptors for the TGF- $\beta$ family. Cell $1992691067-$ 1070.

5 Burger HG. Inhibin. Reproductive Medicine Review 19921 1-20.

6 Groome NP, O'Brien M, Pal R, Rodger FE, Mather J \& McNeilly AS. Two sites immunoassays for inhibins and its subunits. Further applications of the synthetic peptide approach. Journal of Immunological Methods 1993165 167-176.

7 Groome NP, Illingworth PJ, O'Brien M, Pal R, Rodger FE, Mather J et al. Measurement of dimeric inhibin B throughout the human menstrual cycle. Journal of Clinical Endocrinology and Metabolism 199681 1401-1405.

8 Anawalt BD, Bebb RA, Matsumato AM, Groome NP, Illingworth PJ, McNeilly AS et al. Serum inhibin B levels reflect Sertoli cell function in normal men and in men with testicular dysfunction. Journal of Clinical Endocrinology and Metabolism $1996813341-$ 3345.

9 Majumdar SS, Winters SJ \& Plant TM. A study of the relative roles of follicle stimulation hormone and luteinizing hormone in the regulation of testicular inhibin secretion in the Rhesus monkey (Macaca mulatta). Endocrinology 1997138 1363-1373.

10 Lejeune H, Chuzel F, Sanchez P, Durand P, Mather J \& Saez JM. Stimulating effects of both human recombinant inhibin A and activin A on immature porcine Leydig cell functions in vitro. Endocrinology 1997138 4783-4791.

11 Hsueh AJW, Dahl KD, Vaughan J, Tucker E, Rivier J, Bardin C et al. Heterodimers and homodimers of inhibin subunits have different paracrine action in the modulation of luteinizing hormonestimulated androgen biosynthesis. Proceedings of the National Academy of Sciences of the USA 198784 5082-5086.

12 Berensztein E, Belgorosky A \& Rivarola MA. Primary culture of human prepubertal testicular cells isolated from testes collected at necropsy. Acta Endocrinologica 1992127 66-71.

13 Berensztein E, Belgorosky A, García de Dávila MT \& Rivarola MA. Basal testosterone secretion and response to hLH, hFSH and hGH in culture of cells isolated from testes of infants and children. Pediatric Research 199538 592-597.

14 Steinberger E. Cytochemical study of delta 3 beta hydroxysteroid dehydrogenase in testicular cells grown in vitro. Endocrinology 196679 406-410.

15 Saez JM. Leydig cells: endocrine, paracrine and autocrine regulation. Endocrine Reviews 199415 574-626.

16 Radetti G, Bozzola M, Paganini C, Valentini R, Gentili L, Tettoni K et al. Growth hormone bioactivity and levels of growth hormone, growth hormone-binding protein, insulin-like growth factor-I, and insulin-like growth factor-binding proteins in premature and full-term newborns during the first month of life. Archives of Pediatrics and Adolescent Medicine 1997151 170-175.

17 De Zegher F, Denlieger H \& Veldhuis JD. Properties of growth hormone and prolactin hypersecretion by the human infant on the day of birth. Journal of Clinical Endocrinology and Metabolism 199376 1177-1181.

18 Kelly PA, Djiane J, Postel-Vinay MC \& Edery M. The prolactingrowth hormone receptor family. Endocrine Reviews 199112 235-251.

19 Andersson A-M, Juuls A, Petersen JH, Müller J, Groome NP \& Skakkebaek NE. Serum inhibin B in healthy pubertal adolescent boys: relation to age, stage of puberty, and follicle-stimulating hormone, luteinizing hormone, testosterone and estradiol levels. Journal of Clinical Endocrinology and Metabolism 199782 39763981.

Received 20 September 1999

Accepted 15 January 2000 